University at Albany, State University of New York

Scholars Archive

Educational Theory and Practice Faculty

Scholarship

Educational Theory and Practice

2009

\title{
Promoting Learning and Achievement Through Self-Assessment
}

Heidi Andrade

University at Albany, State University of New York, handrade@albany.edu

Anna Valtcheva

University at Albany, State University of New York

Follow this and additional works at: https://scholarsarchive.library.albany.edu/etap_fac_scholar

Part of the Education Commons

\section{Recommended Citation}

Andrade, Heidi and Valtcheva, Anna, "Promoting Learning and Achievement Through Self-Assessment" (2009). Educational Theory and Practice Faculty Scholarship. 12.

https://scholarsarchive.library.albany.edu/etap_fac_scholar/12

This Article is brought to you for free and open access by the Educational Theory and Practice at Scholars Archive. It has been accepted for inclusion in Educational Theory and Practice Faculty Scholarship by an authorized administrator of Scholars Archive. For more information, please contact scholarsarchive@albany.edu. 


\section{Heidi Andrade}

\section{Promoting Learning and Achievement Through Self-Assessment}

Criteria-referenced self-assessment is a process during which students collect information about their own performance or progress; compare it to explicitly stated criteria, goals, or standards; and revise accordingly. The authors argue that self-assessment must be a formative type of assessment, done on drafts of works in progress: It should not be a matter of determining one's own grade. As such, the purposes of self-assessment are to identify areas of strength and weakness in one's work in order to make improvements and promote learning. Criteria-referenced selfassessment has been shown to promote achievement. This article introduces criteria-referenced

Heidi Andrade is an assistant professor and Anna Valtcheva is a research assistant, both in the School of Education at the University at Albany.

Correspondence can be addressed to Heidi Andrade, School of Education, University at Albany, 1400 Washington Avenue, ED 233, Albany, NY 1222. E-mail: handrade@uamail.albany.edu self-assessment, describes how it is done, and reviews some of the research on its benefits to students.

A FORMATIVE CONCEPTION OF assessment honors the crucial role of feedback in learning. Research has clearly shown that feedback promotes learning and achievement (Bangert-Drowns, Kulik, Kulik, \& Morgan, 1991; Brinko, 1993; Butler \& Winne, 1995; Crooks, 1988), yet most students get little informative feedback on their work (Black \& Wiliam, 1998). The scarcity of feedback in most classrooms is due, in large part, to the fact that few teachers have the luxury of regularly responding to each student's work. Fortunately, research also shows that students themselves can be useful sources of feedback via self-assessment (Andrade \& Boulay, 2003; Andrade, Du, \& Wang, 2008; Ross, Rolheiser, \& HogaboamGray, 1999). Self-assessment is a key element in formative assessment because it involves 
students in thinking about the quality of their own work, rather than relying on their teacher as the sole source of evaluative judgments.

Self-assessment is a process of formative assessment during which students reflect on the quality of their work, judge the degree to which it reflects explicitly stated goals or criteria, and revise accordingly. The emphasis here is on the word formative: Self-assessment is done on drafts of works in progress in order to inform revision and improvement: It is not a matter of having students determining their own grades. Selfevaluation, in contrast, refers to approaches that involve students in grading their work, perhaps as part of their final grade for an assignment or a class. Given what we know about human nature, as well as findings from research regarding students' tendency to inflate self-evaluations when they will count toward formal grades (Boud \& Falchikov, 1989), we subscribe to a purely formative type of student self-assessment.

\section{The Purposes of Self-Assessment}

The primary purposes of engaging students in careful self-assessment are to boost learning and achievement, and to promote academic selfregulation, or the tendency to monitor and manage one's own learning (Pintrich, 2000; Zimmerman \& Schunk, 2004). Research suggests that self-regulation and achievement are closely related: Students who set goals, make flexible plans to meet them, and monitor their progress tend to learn more and do better in school than students who do not. Self-assessment is a core element of self-regulation because it involves awareness of the goals of a task and checking one's progress toward them. As a result of selfassessment, both self-regulation and achievement can increase (Schunk, 2003).

\section{The Features of Criteria-Referenced Self-Assessment}

Although even young students typically are able to think about the quality of their own work, they do not always do so, perhaps because one or more necessary conditions are not present. In order for effective self-assessment to occur, students need (according to Goodrich, 1996):

- awareness of the value of self-assessment,

- access to clear criteria on which to base the assessment

- a specific task or performance to assess,

- models of self-assessment,

- direct instruction in and assistance with selfassessment,

- practice,

- cues regarding when it is appropriate to selfassess, and

- opportunities to revise and improve the task or performance.

This list of conditions might seem prohibitive, but student self-assessment is feasible and is occurring in many schools around the world (Deakin-Crick, Sebba, Harlen, Guoxing, \& Lawson, 2005). Several of the key conditions listed above, including modeling, cueing, direct instruction, and practice, are commonly employed classroom practices. The second condition-access to clear criteria on which to base self-assessmentcan be met by introducing a rubric.

A rubric is usually a one- or two-page document that lists criteria and describes varying levels of quality, from excellent to poor, for a specific assignment (Andrade, 2000; Arter \& Chappuis, 2007; Goodrich, 1997). See Appendix A (available online, under the title of this article at http://ehe.osu.edu/tip/contents.cfm) for an example of a rubric that fits this definition. Although many teachers now use rubrics as scoring guides to grade student work, at their best rubrics can serve dual purposes: They can teach, as well as evaluate (Andrade \& Du, 2005; Arter \& McTighe, 2001; Stiggins, 2001). A good rubric describes the kinds of mistakes students tend to make, as well as the ways in which good work shines. It gives students valuable information about the task they are about to undertake and takes the guess-work out of understanding their learning targets, or what counts as high quality work. When used to scaffold self-assessment, 
rubrics can promote learning by creating the three conditions identified by Sadler (1989) for helping students to improve:

The student comes to hold a concept of quality roughly similar to that held by the teacher, is able to monitor continuously the quality of what is being produced during the act of production itself, and has a repertoire of alternative moves or strategies from which to draw at any given point. (p. 121)

There are a number of ways to engage students in effective self-assessment (e.g., Gregory, Cameron, \& Davies, 2000; Paris \& Paris, 2001; Ross et al., 1999; Stallings \& Tascione, 1996). In general, the process involves the following three steps:

1. Articulate expectations. The expectations for the task or performance are clearly articulated, either by the teacher, by the students, or both. Because students become better acquainted with the task at hand when they are involved in thinking about what counts and how quality is defined (Nicol \& Macfarlane-Dick, 2006), Andrade provides students with a rubric, often by cocreating all or part of it in class by analyzing and critiquing examples of strong and weak pieces of student work (Andrade \& Boulay, 2003; Andrade et al., 2008). Ross and colleagues (1999) described a process of cocreating rubrics that differs only in the timing of the model or anchor papers: The teachers in their study used anchor papers to illustrate the levels on the completed rubric after it had been handed out.

2. Self-assessment. Students create rough or first drafts of their assignment, be it an essay, word problem, lab report, volleyball serve, or speech. They monitor their progress on the assignment by comparing their performancesin-progress to the expectations. An example from writing (Andrade et al., 2008) involves students in seeking evidence of success in their drafts. Using colored pencils or highlighters, students underline key phrases in the rubric with one color, then underline or circle in their drafts the evidence of having met the standard articulated by the phrase. For example, students would underline clearly states an opinion in blue on their persuasive essay rubric, then underline their opinions in blue in their persuasive essay drafts. To assess one aspect of sentence fluency, they would underline sentences begin in different ways in yellow on their rubric, use the same yellow pencil to circle the first word in every sentence in their essays, and then say the circled words out loud with an ear for repetition. If students find they have not met a particular standard, they write themselves a reminder to make improvements when they write their final drafts. This process is followed for each criterion on the rubric, with pencils of various colors. The procedure can take one or two class periods: Students in an English class can look at global criteria such as ideas and content, organization, and voice on one day, then self-assess more finegrained criteria like word choice, sentence fluency, and conventions another day.

3. Revision. Students use the feedback from their self-assessments to guide revision. This last step is crucial. Students are savvy, and will not self-assess thoughtfully unless they know that their efforts can lead to opportunities to actually make improvements and possibly increase their grades.

This three-step process can be enhanced with peer assessment and teacher feedback, of course. Just these three steps, however, have been associated with significant improvements in students' writing (Andrade et al., 2008).

\section{The Value of Criteria-Referenced Self-Assessment}

Some research (Andrade, 2001) suggests that simply handing out and explaining a rubric may increase students' knowledge of the criteria for an assignment and help students produce work of higher quality - or it may not. Simply handing out a rubric does not guarantee much of anything. Actively involving students in using 
a rubric to self-assess their work, however, has been associated with noticeable improvements in students' work. Research on the effects of student self-assessment covers a wide range of content areas including English writing (Evans, 2001; Hart, 1999; Wilcox, 1997; Yancey, 1998), social studies (Lewbel \& Hibbard, 2001), mathematics (Adams, 1998; Ross, Hogaboam-Gray, \& Rolheiser, 2002; Stallings \& Tascione, 1996), science (Duffrin, Dawes, Hanson, Miyazaki, \& Wolfskill, 1998; White \& Frederiksen, 1998), and external examinations (MacDonald \& Boud, 2003). In each case, students were either engaged in written forms of self-assessment using journals, checklists, and questionnaires; or oral forms of self-assessment, such as interviews and studentteacher conferences. To date, the bulk of the research on criteria-referenced self-assessment has been done on writing and mathematics.

\section{Writing}

A study of seventh- and eighth-grade students' writing by Andrade and Boulay (2003) found a positive relationship between self-assessment and quality of writing, especially for girls. Ross et al. (1999) have reported that weak writers in fourth, fifth, and sixth grade who were trained in self-assessment of narrative writing outperformed weak writers in the comparison group. They noted that changes in conventions of language (sentence structure, grammar, and spelling) were negligible: The higher posttest scores of the weakest writers were the result of stronger performance on substantive criteria such as plot development, including the "integration of story elements around a central theme" and "the adoption of a narrative voice" (p. 124).

Andrade et al. (2008) also looked at the effectiveness of rubric-referenced self-assessment on scores on elementary school students' writing. Their findings indicated that having students use model papers to generate criteria for a writing assignment and using a rubric to self-assess first drafts is positively related to the quality of their subsequent writing. Like Ross and his colleagues (1999), Andrade et al. (2008) found that the improvements in students' writing included more effective handling of sophisticated qualities such as ideas and content, organization, and voice. When the findings of this study were translated into typical classroom grades, the average grade for the group that engaged in rubric-referenced self-assessment was a low $B$, but the average grade for the comparison group was a high $\mathrm{C}$.

\section{Mathematics}

Mathematics teachers Stallings and Tascione (1996) have employed student self-assessment and self-evaluation in high-school and college mathematics classes. They solicited students' self-assessments after group and individual tests that consisted of a set of mathematics problems. Before the tests, the students and teacher coestablished a set of criteria for grading, including neatness of the paper, proper procedures, and correct answers. Then the teacher graded the students' test performance according to the agreed-upon criteria, marked the students' errors, and recorded the grades only in her own records so as not to influence the students' self-assessment. After the tests were returned, each student was required to submit a written assessment of test performance that contained corrections of all errors and an analysis of test performance according to the list of criteria developed through in-class discussion.

Stallings and Tascione (1996) found that the processes of self-assessment and self-evaluation can "engage students in evaluating their progress, aid in developing their communication skills, and increase their mathematics vocabulary" (p. 548). Students began to assess the performance of their other classroom tasks midway through the semester, even though self-assessment was not required. The researchers also found that students were communicating "more readily, more deliberately, and in greater detail" (p. 551) than students in previous classes. Most of the students were found to check their work more readily. At the end of the semester, a student commented that the practices of self-assessment and correction engaged him in learning the material on the tests, which he would otherwise throw in a drawer. Stallings and Tascione took that student's comments, which were typical of remarks on the 
self-assessment practices, as a sign of improved learner autonomy through self-assessment.

More recent empirical research has produced similar results. In a study of fifth- and sixthgrade math classes, Ross et al. (2002) found that students who were taught to self-assess outperformed other students on word problems. The difference was such that "a student at the 50th percentile in the control group would have performed at the 66th percentile if he or she had been in the treatment group. If the 50th percentile were viewed as the cut-point defining a pass, the proportion of successful students increased by $32 \%$ in the treatment" (p. 53). Black, Harrison, Lee, Marshall, and Wiliam's (2003) study of formative assessment practices in math and science classes for 11- to 15-yearolds also revealed a strong relationship between formative assessment, including self-assessment and achievement. These authors concluded that "the development of self-assessment by the student might have to be an important feature of any programme of formative assessment" (p. 14).

\section{Student Responses to Self-Assessment}

Students tend to embrace rubric-referenced self-assessment for a variety of reasons related to achievement and motivation. A study of undergraduate students' experiences with checklistor rubric-referenced self-assessment (Andrade \& $\mathrm{Du}, 2007$ ) indicated that students felt that selfassessment was valuable, but they needed support and practice in order to reap the full benefits of the process. Andrade and Du reported six main findings:

1. Students' attitudes toward self-assessment tended to become more positive as they gained experience with it. Although many students initially perceived of the requirement to selfassess as "a big pain" (Andrade \& Du, 2007, p. 164), they were unanimous in reporting positive attitudes toward it after having done it.

2. Students felt they could self-assess effectively and were more likely to self-assess when they knew what their teacher expected. Although students admitted that they did not always read their teacher's written expectations as carefully as they should, they craved clearly articulated requirements, criteria, and standards. Students reported that they selfassessed mostly when they knew what the teacher's expectations were. Little or no formal self-assessment was done when expectations were not articulated.

3. Self-assessment involved checking progress, followed by revising and reflecting. Students reported using criteria-referenced selfassessment to check on their works in progress, to guide revisions, and to reflect on their understanding of a topic. Some students admitted that they did not self-assess as often as they should and that, at least at first, they did the formal self-assessment only because it was required. Other students said their selfassessment was relatively mindless until they found that careful self-assessment could help them do better work and get better grades. They also noted that when they did selfassess, they usually used their judgments to guide revision. However, they would use their self-assessments to revise only if they had an opportunity to resubmit their work for a new, presumably higher, grade.

4. Students believed there were multiple benefits of self-assessment. Students said that criteriareferenced self-assessment helped them focus on key elements of an assignment, learn the material, increase their effectiveness in identifying strengths and weaknesses of their work, increase their motivation and mindfulness, and even decrease anxiety. Some students said the self-assessment made them feel more confident about their work. New research (Andrade, Wang, Du, \& Akawi, in press) suggests that girls' self-efficacy or confidence for writing may be especially responsive to rubric-referenced self-assessment.

5. Students reported that transfer of the selfassessment process to other courses was spotty. A few students reported transferring both the process of and the criteria for selfassessment from the class in which it was 
required to other classes. Others, however, admitted they were not consistent in selfassessing. Most students admitted that they did not self-assess enough, or at all, in other classes. They cited a lack of motivation and a lack of support for self-assessment among the reasons they "slip" (Andrade \& Du, 2007, p. 166).

6. There was sometimes a tension between teachers' expectations and students' own standards of quality. Some students were troubled by the fact that their teachers' expectations clashed with their own standards. The difference between self-assessment and "giving [teachers] what they want" was a recurring theme in the study. For example, one student commented: "We're trained to spew out what the teacher wants but, and that's where, and I'm not sure if this says that we're self-assessing or that we're simply just breaking down what the teacher wants in the paper. Basically you're just giving them what they want $::$ : it is selfassessing but what is it self-assessing, it's selfassessing what the teacher wants in the paper" (Andrade \& Du, 2007, p. 168). Andrade and $\mathrm{Du}$ concluded that this tension could be addressed through conversations between teachers and students about the matches and mismatches in their definitions of quality, and by codefining criteria for a given assignment.

Andrade and Du's (2007) findings generally mirror the results of a study of teacher professional development on middle and high school students' attitudes toward self-evaluation by Ross, Rolheiser, and Hogaboam-Gray (1998), with one glaring exception: Students in the latter study tended to develop more negative attitudes toward self-evaluation over the course of the 8-week intervention. Interestingly, the self-evaluation done by those students counted toward $5 \%$ of their final grades. It may not be surprising, then, that students voiced concerns about fairness and the possibility of cheating by inflating self-evaluations. This finding reinforces our commitment to formative uses of student selfassessment.

\section{Conclusions and Encouragement}

Blurring the distinction between instruction and assessment through the use of criteriareferenced self-assessment can have powerful effects on learning. The effect can be both shortterm, as when self-assessment influences student performance on a particular assignment, as well as long-term, as students become more selfregulated in their learning. We encourage educators and researchers to take advantage of what we now know about the conditions under which self-assessment is likely to meet with success. Ross (2006) recommended the following:

1. define the criteria by which students assess their work,

2. teach students how to apply the criteria,

3. give students feedback on their selfassessments, and

4. give students help in using self-assessment data to improve performance.

We recommend two additional conditions:

1. provide sufficient time for revision after selfassessment, and

2. do not turn self-assessment into selfevaluation by counting it toward a grade.

Under these conditions, criteria-referenced selfassessment can ensure that all students get the kind of feedback they need, when they need it, in order to learn and achieve.

\section{References}

Adams, T. L. (1998). Alternative assessment in elementary school mathematics. Childhood Education, 74, 220-224.

Andrade, H. (2000). Using rubrics to promote thinking and learning. Educational Leadership, 57(5), 1318.

Andrade, H. (2001). The effects of instructional rubrics on learning to write. Current Issues in Education, 4(4). Retrieved January 10, 2008, from http://cie. ed.asu.edu/volume4/number4/ 
Andrade, H., \& Boulay, B. (2003). Gender and the role of rubric-referenced self-assessment in learning to write. Journal of Educational Research, 97, 2134.

Andrade, H., \& Du, Y. (2005). Knowing what counts and thinking about quality: students report on how they use rubrics. Practical Assessment, Research and Evaluation, 10(4). Available online at: http:// PAREonline.net/getvn.asp?vD10\&nD3

Andrade, H., \& Du, Y. (2007). Student responses to criteria-referenced self-assessment. Assessment and Evaluation in Higher Education, 32, 159-181.

Andrade, H., Du, Y., \& Wang, X. (2008). Putting rubrics to the test: The effect of a model, criteria generation, and rubric-referenced self-assessment on elementary school students' writing. Educational Measurement: Issues and Practices, 27(2), 3-13.

Andrade, H., Wang, X., Du, Y., \& Akawi, R. (in press). Rubric-referenced assessment and self-efficacy for writing. The Journal of Educational Research.

Arter, J., \& Chappuis, J. (2007). Creating and recognizing quality rubrics. Upper Saddle River, NJ: Pearson/Merrill Prentice Hall.

Arter, J., \& McTighe, J. (2001). Scoring rubrics in the classroom: Using performance criteria for assessing and improving student performance. Thousand Oaks, CA: Corwin Press.

Bangert-Drowns, R. L., Kulik, C. C., Kulik, J. A., \& Morgan, M. T. (1991). The instructional effect of feedback in test-like events. Review of Educational Research, 61, 213-238.

Black, P., Harrison, C., Lee, C., Marshall, B. \& Wiliam, D. (2003). Assessment for learning: Putting it into practice. Berkshire, England: Open University Press.

Black, P., \& Wiliam, D. (1998). Inside the black box: Raising standards through classroom assessment. Phi Delta Kappan, 80, 139-148.

Boud, D., \& Falchikov, N. (1989). Quantitative studies of student self-assessment in higher education: A critical analysis of findings. Higher Education, 18, 529-549.

Brinko, L. T. (1993). The practice of giving feedback to improve teaching. Journal of Higher Education, 64, 574-593.

Butler, D., \& Winne, P. (1995). Feedback and selfregulated learning: A theoretical synthesis. Review of Educational Research, 65, 245-281.

Crooks, T. (1988). The impact of classroom evaluation practices on students. Review of Educational Research, 58, 438-481.
Deakin-Crick, R., Sebba, J., Harlen, W., Guoxing, Y., \& Lawson, H. (2005). Systematic review of research evidence of the impact on students of self- and peer-assessment. Protocol. In Research Evidence in Education Library. London: EPPICentre, Social Science Research Unit, Institute of Education, University of London.

Duffrin, N., Dawes, W., Hanson, D., Miyazaki, J., \& Wolfskill, T. (1998). Transforming large introductory classes into active learning environments. Journal of Educational Technology Systems, 27, 169-78.

Evans, K. A. (2001). Rethinking self-assessment as a tool for response. Teaching English in the Two-Year College, 28, 293-301.

Goodrich, H. (1996). Student self-assessment: At the intersection of metacognition and authentic assessment. Unpublished doctoral dissertation, Harvard University, Cambridge, MA.

Goodrich, H. (1997). Understanding rubrics. Educational Leadership, 54(4), 14-17.

Gregory, K., Cameron, C., \& Davies, A. (2000). Self-assessment and goal-setting. Merville, Canada: Connection.

Hart, D. (1999). Opening assessment to our students. Social Education, 63, 343-345.

Lewbel, S. R., \& Hibbard, K. M. (2001). Are standards and true learning compatible? Principal Leadership (High School Ed.), 1(5), 16-20.

MacDonald, B., \& Boud, D. (2003). The impact of self-assessment on achievement: The effects of selfassessment training on performance in external examinations. Assessment in Education, 10, 209220.

Nicol, D., \& Macfarlane-Dick, D. (2006). Formative assessment and self-regulated learning: A model and seven principles of good feedback practice. Studies in Higher Education, 31, 199-218.

Paris, S. G., \& Paris, A. H. (2001). Classroom applications of research on self-regulated learning. Educational Psychologist, 36, 89-101.

Pintrich, P. (2000). The role of goal orientation in selfregulated learning. In M. Boekaerts, P. Pintrich, \& M. Zeidner (Eds.), Handbook of self-regulation (pp. 452-502). San Diego, CA: Academic Press.

Ross, J. (2006). The reliability, validity, and utility of self-assessment. Practical Assessment, Research, and Evaluation, 11(10). Retrieved January 11, 2007, from http://pareonline.net/getvn.asp?vD11\& nD10

Ross, J. A., Hogaboam-Gray, A., \& Rolheiser, C. (2002). Student self-evaluation in grade 5-6 math- 
ematics effects on problem-solving achievement. Educational Assessment, 8, 43-59.

Ross, J. A., Rolheiser, C., \& Hogaboam-Gray, A. (1998). Skills-training versus action research inservice: Impact on student attitudes to selfevaluation. Teaching and Teacher Education, 14, 463-477.

Ross, J. A., Rolheiser, C., \& Hogaboam-Gray, A. (1999). Effects of self-evaluation training on narrative writing. Assessing Writing, 6, 107-132.

Sadler, D. R. (1989). Formative assessment and the design of instructional systems. Instructional Science, 18, 119-144.

Schunk, D. (2003). Self-efficacy for reading and writing: Influence of modeling, goal-setting, and selfevaluation. Reading \& Writing Quarterly, 19, 159172.

Stallings, V., \& Tascione, C. (1996). Student self-assessment and self-evaluation. Mathematics Teacher, 89, 548-55.
Stiggins, R. J. (2001). Student-involved classroom assessment (3rd ed.). Upper Saddle River, NJ: Merrill/ Prentice-Hall.

White, B. Y., \& Frederiksen, J. R. (1998). Inquiry, modeling, and metacognition: Making science accessible to all students. Cognition and Instruction, 16, 3-118.

Wilcox, B. L. (1997). Writing portfolios: Active vs. passive. English Journal, 86, 34-7.

Yancey, K. B. (1998). Getting beyond exhaustion: Reflection, self-assessment, and learning. Clearing House, 72, 13-17.

Zimmerman, B., \& Schunk, D. (2004). Self-regulating intellectual processes and outcomes: A social cognitive perspective. In D. Dai \& R. Sternberg (Eds.), Motivation, emotion, and cognition: Integrative perspectives on intellectual functioning and development (pp. 323-349). Mahwah, NJ: Lawrence Erlbaum Associates. 